\title{
UCP2, UCP3 and leptin gene expression: modulation by food restriction and leptin
}

\author{
P J Scarpace ${ }^{1}$, M Nicolson $^{2}$ and $\mathbf{M}$ Matheny ${ }^{1}$ \\ ${ }^{1}$ Geriatric Research, Education and Clinical Center, Department of Veterans Affairs Medical Center, Gainesville, Florida 32608-1197, USA \\ and Department of Pharmacology and Therapeutics, University of Florida College of Medicine, Gainesville, Florida 32610, USA and ${ }^{2}$ Amgen, \\ Thousand Oaks, California 91320, USA \\ (Requests for offprints should be addressed to P J Scarpace, Geriatric Research, Education and Clinical Center (182), Department of Veterans Affairs Medical \\ Center, Gainesville, Florida 32608-1197, USA)
}

\begin{abstract}
To determine the effects of food restriction and leptin administration on several transcripts involved in energy homeostasis, we examined leptin, uncoupling proteins (UCP) 1, 2 and 3, lipoprotein lipase (LPL), $\beta_{3}$-adrenergic receptors $\left(\beta_{3} \mathrm{AR}\right)$ and hormone-sensitive lipase (HSL) mRNA levels in brown adipose tissue (BAT) and epididymal (EWAT) and perirenal (PWAT) white adipose tissue in three groups of rats. The groups were administered leptin for 1 week, or had food restricted to the amount of food consumed by the leptin-treated animals, or had free access to food. Leptin administration increased serum leptin concentrations 50-fold and decreased food consumption by $43 \%$, whereas serum insulin and corticosterone concentrations were unchanged. Leptin increased LPL mRNA by $80 \%$, UCP1 mRNA twofold, and UCP3 mRNA levels by $62 \%$ in BAT, and increased UCP2 mRNA levels twofold in EWAT. In contrast,
\end{abstract}

UCP2 mRNA levels were unchanged in PWAT and BAT. In WAT from food-restricted rats, leptin gene expression was diminished by $40 \%$ compared with those fed ad libitum. With leptin administration, there was a further $50 \%$ decrease in leptin expression. LPL mRNA levels were decreased by food restriction but not by leptin in WAT, whereas $\beta_{3} \mathrm{AR}$ and HSL mRNA levels were unchanged with either food restriction or leptin treatment. The present study indicates that leptin increases the gene expression of UCP2 in EWAT and that of UCP1, UCP3 and LPL in BAT, whereas reduced food consumption but not leptin, decreases LPL expression in WAT. In addition, with leptin administration there is a decrease in leptin gene expression in WAT, independent of food intake and serum insulin and corticosterone concentrations.

Journal of Endocrinology (1998) 159, 349-357

\section{Introduction}

Leptin, the product of the ob gene, is one factor involved in body weight maintenance, and this hormone contributes to the regulation of both food intake and energy expenditure (Campfield et al. 1995, Halaas et al. 1995, Pelleymounter et al. 1995, Scarpace et al. 1997). The mechanism of increased energy expenditure appears to involve increased thermogenesis in brown adipose tissue (BAT). We previously reported that leptin administration increases thermogenesis in BAT, including increases in oxygen consumption and uncoupling protein 1 (UCP1) gene expression (Scarpace et al. 1997). Thermogenesis in BAT is mediated by sympathetically innervated $\beta_{3^{-}}$ adrenergic receptors (Scarpace et al. 1992). This process accelerates lipolysis, and the liberated fatty acids serve as substrates for mitochondrial oxidation and provide the signal to activate UCP1. This protein uncouples mitochondria, producing high rates of substrate oxidation and an increase in heat production without the phosphoryl-

ation of adenosine $5^{\prime}$-diphosphate (ADP) (Klingenberg 1990). In addition to activating thermogenesis, $\beta_{3^{-}}$ adrenergic receptors upregulate the gene expression of UCP1 (Scarpace et al. 1994).

Recently, two additional uncoupling proteins, UCP2 and UCP3, have been identified (Boss et al. 1997b, Fleury et al. 1997, Vidal-Puig et al. 1997). These uncoupling proteins have $59 \%$ and $57 \%$ homology, respectively, with UCP1 and 73\% homology with each other (Fleury et al. 1997, Vidal-Puig et al. 1997). In common with UCP1, both UCP2 and UCP3 can partially uncouple mitochondrial respiration (Fleury et al. 1997, Gong et al. 1997). The expression of UCP2 and UCP3, unlike UCP1, is not limited to BAT. UCP3 is expressed mainly in BAT and skeletal muscle, whereas UCP2 is widely expressed in many tissues, including white adipose tissue (WAT), heart, and muscle in both rodents and humans (Fleury et al. 1997, Vidal-Puig et al. 1997). In Zucker rats, in which the leptin gene was overexpressed, UCP2 gene expression was increased in WAT (Zhou et al. 1997). In

Journal of Endocrinology (1998) 159, 349-357 C 1998 Society for Endocrinology Printed in Great Britain 0022-0795/98/0159-349 \$08.00/0 
addition, leptin increases the gene expression of UCP3 in muscle and BAT of ob/ob mice, in which the expression of UCP3 is low (Gong et al. 1997). Whether administration of leptin to normal rats upregulates UCP2 and UCP3 gene expression is unknown. We hypothesized that leptin administration, in addition to increasing UCP1 expression, should also increase UCP2 and UCP3 expression.

In addition to mediating thermogenesis in BAT, $\beta_{3^{-}}$ adrenergic receptors negatively regulate the gene expression of leptin in WAT (Slieker et al. 1996, Li et al. 1997). Leptin is primarily synthesized in WAT (Zhang et al. 1994, Murakami \& Shima 1995, Trayhurn et al. 1995b). Fasting decreases leptin gene expression, whereas subsequent refeeding increases expression ( $\mathrm{Li}$ et al. 1997, Saladin et al. 1995, Trayhurn et al. 1995b). Insulin and the glucocorticoids also increase leptin gene expression (Slieker et al. 1996, De Vos et al. 1995, Wabitsch et al. 1996) and may mediate the food intake-induced increase in leptin gene expression, whereas catecholamines may mediate the fasting-induced decrease in leptin gene expression. Thus one mechanism by which leptin may negatively regulate its own synthesis is through the inhibition of food intake. Alternatively, leptin may negatively regulate its own synthesis independently of food intake.

To examine the effects of food restriction and leptin administration on several transcripts involved in energy homeostasis, we examined UCP1, UCP2, UCP3, lipoprotein lipase (LPL), and leptin mRNA levels in BAT and in epididymal (EWAT) and perirenal (PWAT) adipose tissue in three groups of rats: administered leptin for 1 week, or having food restricted to the amount of food consumed by the leptin-treated animals, or having free access to food. In addition, mRNA levels for $\beta_{3^{-}}$ adrenergic receptors $\left(\beta_{3} \mathrm{AR}\right)$ and hormone-sensitive lipase (HSL) were examined.

\section{Materials and Methods}

\section{Animals}

Five-month-old male F-344 $\times$ Brown Norway rats were obtained from Harlan Sprague-Dawley (Indianapolis, IN, USA). Upon arrival, rats were examined and remained in quarantine for 1 week. Animals were cared for in accordance with the principles of the Guide to the Care and Use of Experimental Animals. Rats were housed individually in microisolated cages with a $12: 12 \mathrm{~h}$ light: darkness cycle (light on from 0700 to $1900 \mathrm{~h}$ ). Ambient temperature was $26{ }^{\circ} \mathrm{C}$, which is thermoneutrality for these rats (Scarpace et al. 1994).

\section{Experimental design}

The rats were divided into three groups. The first group was allowed the normal daily consumption of food available ad libitum (Purina Rat Chow), and the second group was given $8.5 \mathrm{~g}$ food per day, which was the level of food consumption observed after administration of leptin to the rats fed ad libitum. The third group was administered mouse leptin ( $1 \mathrm{mg} /$ day) by osmotic minipumps (model 2ML1, Alzet, Palo Alto, CA, USA), implanted subcutaneously along the back of the rats. Osmotic minipumps containing saline were implanted in the rats fed ad libitum and the food-restricted rats. Rats were killed on the 7th day after minipump implantation.

\section{Chemicals}

Mouse leptin was supplied by Amgen (Thousand Oaks, CA, USA). All other chemicals were obtained from Sigma Chemical (St Louis, MO, USA).

\section{Tissue harvesting}

Rats were killed by cervical dislocation under $85 \mathrm{mg} / \mathrm{kg}$ pentobarbital anesthetic. Blood samples were collected by heart puncture and serum harvested by a 30-min centrifugation in serum separator tubes. The circulatory system was perfused with $20 \mathrm{ml}$ cold saline and BAT, epididymal WAT and perirenal WAT excised.

\section{Serum leptin concentrations}

Serum leptin concentrations were measured in a solidphase sandwich enzyme immunoassay (EIA) using a polyclonal rabbit antibody immobilized in microtiter wells (Hotta et al. 1996). The antibody was raised against recombinant leptin and was affinity-purified over a recombinant leptin column. Bound leptin was detected with affinity-purified antibody conjugated to horseradish peroxidase and quantitated with a chromogenic substrate (TMB/peroxide). Leptin concentrations were calculated from standard curves generated for each assay using recombinant mouse leptin and then corrected for the crossreactivity with recombinant rat leptin (43\%).

\section{Insulin and corticosterone}

Insulin concentrations were assayed in a double-antibody reaction using a ruthenylated primary antibody and a biotinylated secondary antibody. The reaction was quantitated by an electrochemiluminescence detection system using the Origen 1.5 analyzer (Igen, Inc., Gaithersburg, MD, USA). Corticosterone was measured by a doubleantibody radioimmunoassay (ICN Biomedicals, Irvine, CA, USA).

\section{DNA assay}

DNA was determined by fluorescence in delipidated tissue (Labarca \& Paigen 1980). WAT (90 mg) was sonicated on 
ice for $15 \mathrm{~s}$ in $500 \mu \mathrm{l} 2 \mathrm{M} \mathrm{NaCl}, 1 \mathrm{mM}$ EDTA, $50 \mathrm{mM}$ $\mathrm{NaPO}_{4}, \mathrm{pH} 7 \cdot 4$ buffer. Lipid was removed by the addition of $7 \mathrm{ml}$ acetone $\left(-20^{\circ} \mathrm{C}\right)$, followed by agitation for $10 \mathrm{~min}$ and centrifugation at $1800 \mathrm{~g}$ for $10 \mathrm{~min}$. The pellet was harvested, resuspended in the above buffer and fluorescence was determined at an emission wavelength of $460 \mathrm{~nm}$ after the addition of bisbenzimide $(1 \mu \mathrm{g} / \mathrm{ml})$ in a Hoefer (San Francisco, CA, USA) Fluormeter Model TK0100.

\section{Northern analysis and $m R N A$ levels}

Total cellular RNA was extracted using a modification of the method of Chomczynski \& Sacchi (1987). The integrity of the isolated RNA was verified using agarose gels (1\%) stained with ethidium bromide. The RNA was quantified by spectrophotometric absorption at $260 \mathrm{~nm}$ using multiple dilutions of each sample.

The probe to detect leptin mRNA was a 33-mer antisense oligonucleotide (5'-GGTCTGAGGCAGGGA GCAGCTCTTGGAGAAGGC) (Trayhurn et al. 1995a) end-labeled using terminal deoxynucleotidyl transferase (Promega, Madison, WI, USA). The oligonucleotide was based on a region of the mRNA downstream from the site of the primary mutation in ob/ob mice (Trayhurn et al. 1995a). We previously demonstrated by Northern analysis that this probe binds to a single mRNA species of $4.1 \mathrm{~kb}$ (Li et al. 1997). The UCP2 cDNA (IMAGE 389584) was provided by Craig Warden (Fleury et al. 1997), the UCP3 cDNA was provided by J-P Giacobino (Boss et al. 1997b), the UCP1 cDNA was provided by Leslie Kozak (Kozak et al. 1988), the $\beta_{3} \mathrm{AR}$ cDNA was provided by James Granneman (Granneman 1991) and mouse LPL and HSL cDNA clones were obtained from the American Tissue Culture Collection (Rockville, MD, USA). The cDNAs were labeled using a random primer kit (Prime-a-Gene, Promega, Madison, WI, USA). For Northern analysis, $20 \mu \mathrm{g}$ extracted total RNA was fractionated by agarose gel electrophoresis for $2 \mathrm{~h}$. The RNA was then transferred to a charged nylon membrane (Gene Screen, Dupont NEN, Boston, MA, USA) by capillary blotting overnight and fixed by baking at $80^{\circ} \mathrm{C}$ for $2 \mathrm{~h}$. For dot blot analysis, several dilutions of the RNA $(0 \cdot 125,0 \cdot 25,0 \cdot 5,1 \cdot 0)$ were immobilized on nylon membranes using a dot blot apparatus (Biorad, Richmond, CA, USA). The membranes were baked at $80{ }^{\circ} \mathrm{C}$ for $2 \mathrm{~h}$. The baked membranes were prehybridized using $25 \mathrm{mM}$ potassium phosphate, $750 \mathrm{mM} \mathrm{NaCl}, 75 \mathrm{mM}$ sodium citrate, $5 \times$ Denhardt's solution, $50 \mu \mathrm{g} / \mathrm{ml}$ denatured salmon sperm DNA and $50 \%$ formamide. After incubation for $14-16 \mathrm{~h}$ at $42{ }^{\circ} \mathrm{C}$, the membranes were hybridized with ${ }^{32} \mathrm{P}$-labeled probes in the prehybridization buffer plus $10 \%$ dextran sulfate. After hybridization for $14-16 \mathrm{~h}$ at $42{ }^{\circ} \mathrm{C}$, the membranes were washed and exposed to a phosphor imaging screen for $48 \mathrm{~h}$. The latent image was scanned using a Phosphor Imager (Molecular Dynamic, Sunnyvale, CA, USA)
Table 1 Serum concentrations of leptin, insulin and corticosterone after administration of leptin. Values represent the mean \pm S.E. of seven or eight rats

\begin{tabular}{|c|c|c|c|}
\hline & $\begin{array}{l}\text { Leptin } \\
(\mathrm{ng} / \mathrm{ml})\end{array}$ & $\begin{array}{l}\text { Insulin } \\
\text { (ng/ml) }\end{array}$ & $\begin{array}{l}\text { Corticosterone } \\
(\mathrm{ng} / \mathrm{ml})\end{array}$ \\
\hline \multicolumn{4}{|l|}{ Treatment } \\
\hline Food-restricted & $4 \cdot 3 \pm 0.5$ & $3 \cdot 5 \pm 0 \cdot 7$ & $148 \pm 18$ \\
\hline Leptin & $200 \pm 65^{* * *}$ & $2 \cdot 6 \pm 0 \cdot 5$ & $228 \pm 29$ \\
\hline Fed ad libitum & $5 \cdot 6 \pm 0 \cdot 9$ & $3 \cdot 4 \pm 0 \cdot 8$ & $184 \pm 31$ \\
\hline
\end{tabular}

${ }^{* * * P}<0 \cdot 001$ compared with other treatments (one-way ANOVA).

and analyzed by Image Quant Software (Molecular Dynamics). Intensities per microgram total cellular RNA were calculated by comparison with internal laboratory standards of WAT or BAT mRNA present on each nylon membrane. To ensure the changes in mRNA levels were specific, nylon membranes probed for leptin mRNA were stripped by brief exposure to boiling water and rehybridized with $\beta$-actin. mRNA levels were expressed in arbitrary units (AU), taking values in food-restricted rats as $100 \mathrm{AU}$.

\section{Statistical analysis}

Data were analyzed by one-way analysis of variance (ANOVA). When the main effect was significant, the post-hoc test was applied to determine individual differences between means.

\section{Results}

\section{Leptin administration}

Leptin administration for 1 week to rats maintained at thermoneutrality increased serum leptin concentrations nearly 50-fold, whereas serum insulin and corticosterone concentrations were unchanged (Table 1). Leptin treatment resulted in a $43 \%$ decrease in food intake (from $16 \pm 0 \cdot 4 \mathrm{~g} /$ day to $9 \pm 1 \cdot 1 \mathrm{~g} /$ day; $P<0 \cdot 001)$. The foodrestricted rats were limited to a food intake of $8.5 \mathrm{~g} /$ day, approximately $50 \%$ of the amount of food consumed by the rats fed ad libitum. Both food restriction and leptin administration resulted in a significant loss of body weight compared with prerestriction weight $(392 \pm 11 \mathrm{~g}$ compared with $333 \pm 9 \mathrm{~g} ; P=0.0023$ for food restriction), but there was no greater loss of body weight in the rats administered leptin (388 \pm 13 g compared with $341 \pm 8$ g; $P=0 \cdot 063)$. In contrast, body weight in the rats fed ad libitum increased (from $368 \pm 6 \mathrm{~g}$ to $376 \pm 8 \mathrm{~g} ; P<0 \cdot 03$ ). With leptin treatment, there was a $36 \%$ decrease in PWAT weight and a $22 \%$ decrease in EWAT weight 
Table 2 White adipose tissue weight, RNA content and DNA content. Values are expressed as total RNA or DNA per fat pad (mean \pm S.E. of eight rats)

PWAT

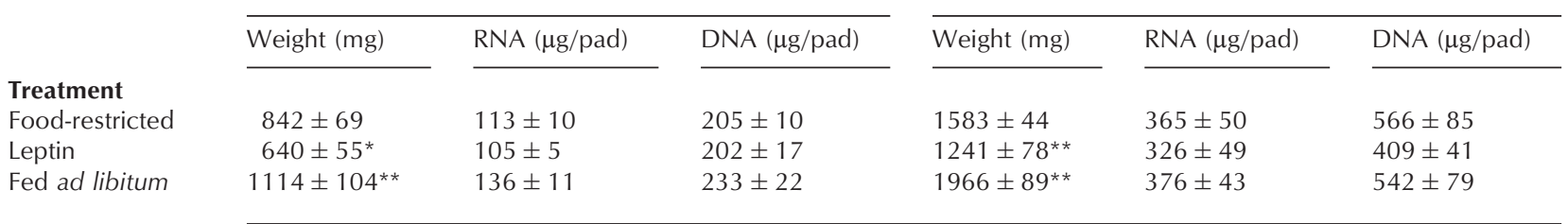

${ }^{*} P<0.005$ for difference between mean weights by one-way ANOVA, $P<0.05$ for difference with leptin treatment compared with food-restricted rats. ${ }^{*} P<0 \cdot 001$ for difference between mean weights by one-way ANOVA, $P<0 \cdot 05$ for difference from food-restricted rats.

(Table 2). Despite the decrease in PWAT and EWAT weight, total RNA and DNA contents were unchanged with leptin administration (Table 2).

\section{UCP1, UCP2 and UCP3 gene expression}

After administration of leptin, UCP2 mRNA levels were examined in BAT, PWAT, and EWAT, whereas UCP1 and UCP3 levels were examined in BAT. Because leptin decreases food intake and any changes in mRNA levels with leptin administration may be secondary to diminished food intake, comparisons were made with rats that had their food restricted to the amount of food consumed by the leptin-treated rats. Northern analysis revealed that the UCP2 probe was bound to a single mRNA species of $1.6 \mathrm{~kb}$ in BAT, EWAT, and lung (data not shown), whereas the UCP1 probe was bound to a major band corresponding to $1.5 \mathrm{~kb}$ and a minor band at $1.9 \mathrm{~kb}$ only in BAT (Scarpace et al. 1994). The UCP3 probe bound to a single mRNA species of $2.6 \mathrm{~kb}$ (data not shown), similar to that reported by Boss et al. (1997b). Leptin administration increased UCP2 mRNA levels nearly twofold in EWAT compared with either food-restricted rats or those fed ad libitum (Fig. 1), and there was no difference in UCP2 mRNA levels between those two groups of rats (Fig. 1). $\beta$-Actin mRNA levels were unchanged with either food restriction or leptin treatment (food restricted, $100 \pm 16$ AU; leptin, $113 \pm 13$ AU; ad libitum, $111 \pm 21$ $\mathrm{AU})$. In contrast to values in EWAT, UCP2 mRNA levels were unchanged with leptin treatment in both PWAT and BAT (Table 3). Leptin treatment increased UCP3 mRNA levels 1.6-fold in BAT compared with either food-restricted rats or those fed ad libitum, and there were no differences in UCP3 mRNA levels between the latter two groups (Fig. 1). In agreement with our previous findings (Scarpace et al. 1997), after leptin administration, UCP1 mRNA levels were increased nearly fourfold in BAT compared with the values in food-restricted rats $(100 \pm 16$ AU compared with $382 \pm 53$ AU; $P<0 \cdot 001)$. As expected, UCP1 mRNA levels in rats fed ad libitum were twofold greater than those in food-restricted rats $(100 \pm 16$ AU compared with $212 \pm 33$ AU; $P<0 \cdot 005)$.
In all experimental conditions, $\beta$-actin mRNA in PWAT and BAT was unchanged with leptin administration or food restriction (Table 3 ).

\section{Leptin $m R N A$ levels}

As expected, when food-restricted rats were compared with those fed ad libitum, the food restriction alone decreased leptin RNA levels by $40 \%$ in both PWAT and EWAT (Fig. 2), whereas $\beta$-actin mRNA levels were unchanged by food restriction (Table 3). Despite the decrease in leptin gene expression, there was only a small, non-significant decrease in serum leptin and no differences in either serum insulin or corticosterone concentrations in food-restricted rats compared with the concentrations in rats fed ad libitum (Table 1). In addition, with food restriction, there was a $24 \%$ non-significant decreases in PWAT weight and a 20\% significant decrease in EWAT

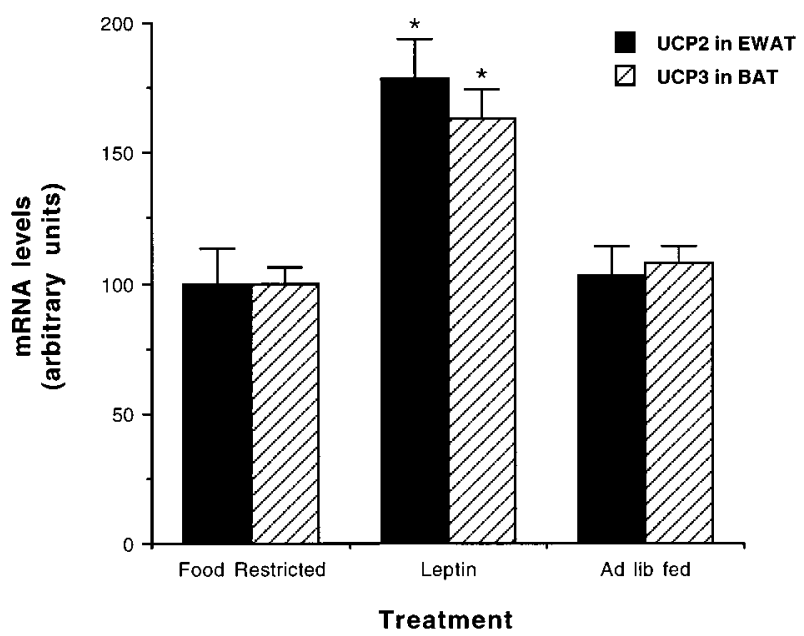

Figure 1 UCP2 mRNA levels in EWAT and UCP3 mRNA levels in BAT from food-restricted rats, leptin-administered rats, and rats fed ad libitum (Ad lib fed). Values represent the mean \pm S.E. of eight rats and are expressed in arbitrary units, with the values for UCP2 and UCP3 mRNA levels in food restricted animals arbitrarily set at 100 and the S.E. adjusted proportionally. ${ }^{*} P<0 \cdot 001$ for difference from food-restricted rats or rats fed ad libitum (one-way ANOVA). 
Table 3 Levels of transcripts in BAT and PWAT after administration of leptin. Values represent the mean \pm S.E. of seven or eight rats, and are expressed as arbitrary units, with the level in food-restricted rats set to 100, and the S.E. adjusted proportionally

\begin{tabular}{|c|c|c|c|c|c|c|}
\hline & \multicolumn{3}{|c|}{ BAT (mRNA/ $\mu \mathrm{g}$ RNA) } & \multicolumn{3}{|c|}{ PWAT (mRNA/ $\mu \mathrm{g}$ RNA) } \\
\hline & Food-restricted & Leptin & Fed ad libitum & Food-restricted & Leptin & Fed ad libitum \\
\hline \multicolumn{7}{|l|}{ Transcript } \\
\hline UCP2 & $100 \pm 4 \cdot 5$ & $103 \pm 9 \cdot 1$ & $90 \pm 5 \cdot 3$ & $100 \pm 7 \cdot 9$ & $100 \pm 11$ & $85 \cdot 7 \pm 5 \cdot 0$ \\
\hline $\mathrm{LPL}$ & $100 \pm 7 \cdot 5$ & $183 \pm 19^{* * *}$ & $105 \pm 10$ & $100 \pm 2 \cdot 9$ & $95 \pm 7 \cdot 1$ & $175 \pm 15^{*}$ \\
\hline HSL & $100 \pm 9 \cdot 9$ & $92 \pm 7 \cdot 0$ & $99 \pm 9 \cdot 1$ & $100 \pm 4 \cdot 5$ & $108 \pm 10$ & $103 \pm 7 \cdot 2$ \\
\hline$\beta_{3} \mathrm{AR}$ & $100 \pm 5 \cdot 5$ & $97 \pm 5 \cdot 1$ & $93 \pm 6 \cdot 8$ & $100 \pm 8 \cdot 3$ & $95 \pm 11$ & $103 \pm 11$ \\
\hline$\beta$-Actin & $100 \pm 8 \cdot 1$ & $112 \pm 12$ & $113 \pm 12$ & $100 \pm 6 \cdot 2$ & $96 \pm 9$ & $120 \pm 10$ \\
\hline
\end{tabular}

${ }^{*} P<0.05$ compared with food-restricted or leptin-treated rats (one-way ANOVA); ${ }^{* * *} P<0.001$ compared with food-restricted rats (one-way ANOVA).

weight, but no changes in DNA or RNA content (Table 2). These data suggest that food restriction diminishes leptin gene expression independently of serum insulin or corticosterone concentrations. After administration of leptin, there was an additional 55\% decrease in leptin mRNA levels per microgram RNA in PWAT and a nearly 50\% decrease in EWAT compared with levels in foodrestricted rats (Fig. 2). Once again, $\beta$-actin mRNA was unchanged with leptin administration (Table 3 ).

When the leptin mRNA data were expressed on a 'per cell' basis - that is, normalized per microgram DNA there were similar 50\% decreases in leptin mRNA levels after administration of leptin (data not shown). The total RNA and DNA contents of PWAT and EWAT were

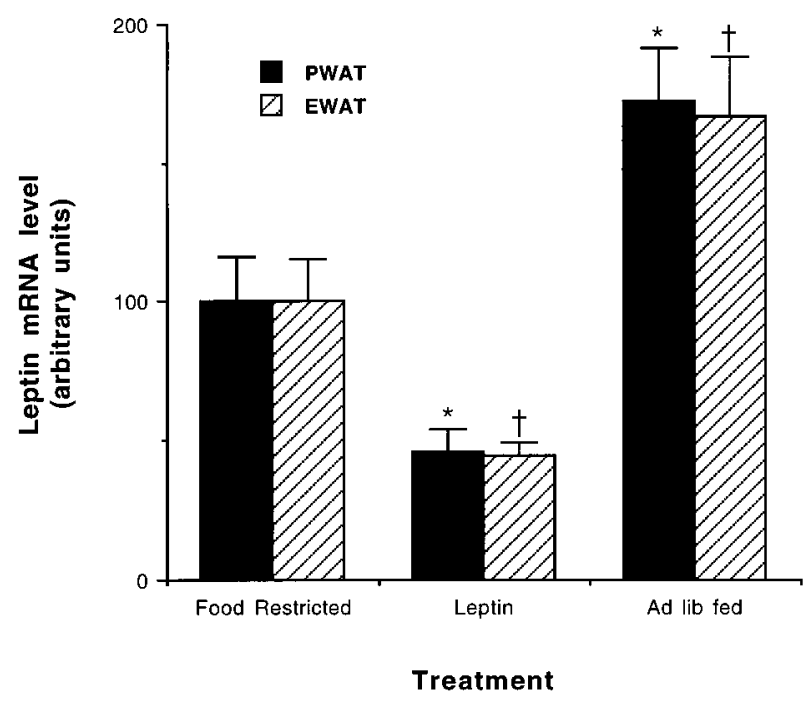

Figure 2 Leptin mRNA levels in PWAT and EWAT in foodrestricted rats, leptin-administered rats, and rats fed ad libitum (Ad lib fed). Values represent the mean \pm S.E. of eight rats and are expressed in arbitrary units, with values for leptin mRNA levels in the food-restricted rats arbitrarily set at 100 and the S.E. adjusted proportionally. ${ }^{*} P<0 \cdot 001$ for difference with treatment and feeding by one-way ANOVA. $P<0.05$ (leptin) or $P<0.01$ (ad libitum fed) for difference from food-restricted rats. ${ }^{\dagger} P<0.001$ for difference with treatment and feeding by one-way ANOVA. $P<0 \cdot 05$ for difference from food-restricted rats. unchanged despite a decrease in tissue weight, suggesting that cell size decreases after both food restriction and leptin administration (Table 2). Cell size may be one factor contributing to the increase in UCP2 mRNA or the decrease in leptin mRNA levels after administration of leptin. However, UCP2 mRNA levels were unchanged with food restriction (Fig. 1), despite the apparent decrease in cell size (Table 2). Moreover, there was a strong correlation between the decrease in leptin mRNA and the increase in UCP2 mRNA levels after administration of leptin (Fig. 3). In contrast, there was no correlation between leptin mRNA and UCP2 mRNA after food restriction (data not shown), the latter of which also decreases cell size (Table 2). These data suggest that the increase in UCP2 mRNA and the decrease in leptin mRNA are more closely associated with leptin administration rather than associated with cell size (Fig. 3).

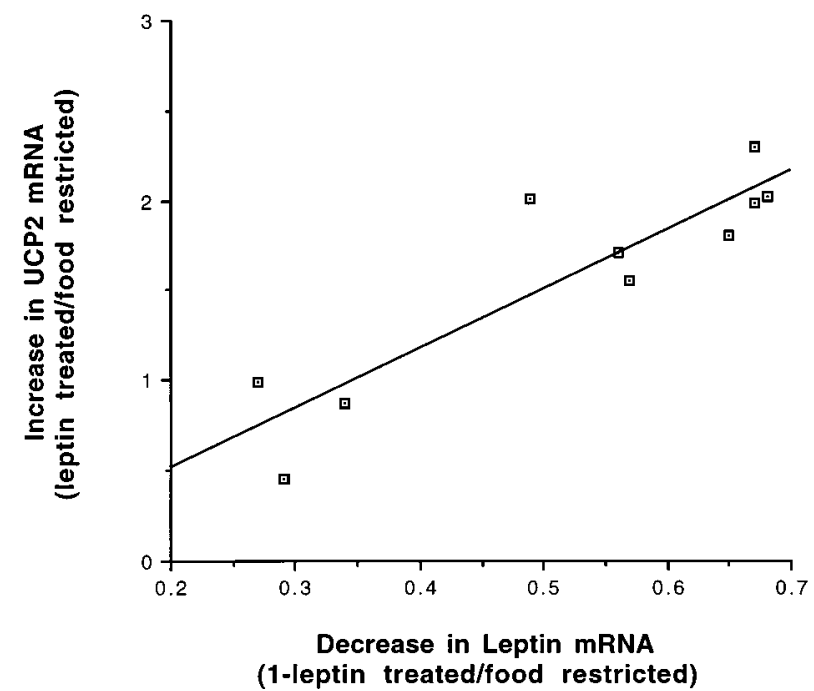

Figure 3 Correlation between the increase in UCP2 mRNA levels after leptin treatment and the decrease in leptin mRNA levels after leptin treatment in EWAT. Each data point represents the ratio of UCP2 or leptin mRNA from an individual rat to the averaged value in the food-restricted rats. Correlation coefficient is 0.81 $(P=0 \cdot 0004)$. 


\section{LPL $m R N A$ levels}

The enzyme, LPL, is involved in the assimilation of triglycerides into both BAT and WAT, and LPL mRNA levels have been reported to be upregulated by $\beta$-adrenergic stimulation in BAT but downregulated in WAT (Auwerx et al. 1992, Trayhurn et al. 1995a). In contrast to its effects on UCP1, food restriction had no effect on LPL mRNA in BAT compared with rats fed ad libitum (Table 3). However, leptin administration increased LPL mRNA by $80 \%$ in BAT compared with that in food-restricted rats (Table 3). In contrast to the effects on BAT, food restriction diminished LPL mRNA levels in PWAT (Table 3) and EWAT (data not shown) by $40 \%$, but there was no further reduction after administration of leptin. Thus the decrease in LPL mRNA after administration of leptin compared with that in rats fed ad libitum appears to be secondary, because of reduced food consumption, rather than a primary effect of leptin.

\section{$H S L$ and $\beta_{3} A R \quad m R N A$}

Leptin administration had no effect on two other transcripts involved in energy balance. HSL and $\beta_{3}$ AR mRNA levels were unchanged in both BAT (Table 3 ) and in PWAT (Table 3). In addition, $\beta_{3}$ AR mRNA levels were examined in EWAT and were found to be unchanged with leptin administration (data not shown).

\section{Discussion}

Leptin contributes to both the negative regulation of food intake and the positive regulation of energy expenditure (Halaas et al. 1995, Pelleymounter et al. 1995, Scarpace et al. 1997). We previously reported that leptin administration increases thermogenesis in BAT, including increases in oxygen consumption and UCP1 gene expression (Scarpace et al. 1997). The present study has extended these findings and demonstrated that leptin also increases the expression of UCP2 in EWAT and UCP3 in BAT. UCP2 and UCP3 (homologues of UCP1) are expressed in a variety of tissues and are capable of uncoupling mitochondrial respiration (Fleury et al. 1997, Vidal-Puig et al. 1997). UCP3, in common with UCP1, is regulated in a manner suggesting a role in thermogenesis and energy balance. In BAT, UCP3 is upregulated by cold, thyroid hormone, and feeding and downregulated by fasting (Gong et al. 1997, Larkin et al. 1997, Boss et al. 1998). In skeletal muscle, UCP3 is upregulated by thyroid hormone but not by cold, and with fasting there is an unexplained increase in UCP3 gene expression (Gong et al. 1997, Larkin et al. 1997, Boss et al. 1998). The biological role of UCP2 is less clear, although some evidence suggests a role for this protein in energy balance and thermogenesis. In UCP1-deficient mice, UCP2 expression in BAT is up regulated, possibly contributing to the surprising absence of obesity in these mice (Enerback et al. 1997). In one study, cold exposure upregulated the expression of UCP2 in BAT (Boss et al. 1997a), but this was not so in another study (Fleury et al. 1997). Fasting upregulated the expression of UCP2 in muscle and adipose tissue of humans (Millet et al. 1997) and in muscle but not BAT of rats (Boss et al. 1997a).

Earlier reports suggested a role for leptin in the regulation of UCP2 and UCP3. In rats in which the leptin gene was overexpressed, UCP2 expression was increased in WAT (Zhou et al. 1997). Leptin also increased UCP3 expression in ob/ob mice (Gong et al. 1997). However, UCP3 mRNA levels were abnormally low in these mice, and the effects of leptin treatment were not investigated in wild-type mice (Gong et al. 1997). The present study extends the previous reports by demonstrating that leptin treatment upregulates both UCP2 mRNA in EWAT and UCP3 mRNA in BAT in rodents without any known gene abnormalities in the leptin pathway. These previous reports, coupled with our data, suggest a role for UCP2 and UCP3 as part of the mechanism by which leptin contributes to energy balance. However, in all these studies, the demonstration of an increase in mRNA levels, which could be the result of an increase either in gene transcription or in stability of mRNA, has not been correlated with a functional response, suggesting the roles for UCP2 and UCP3 are not clearly defined. Furthermore, the lack of increase in UCP2 mRNA levels in PWAT suggests that there is a difference in response to leptin depending on the WAT depot. It is known that leptin synthesis is depot-dependent, with subcutaneous fat contributing to serum leptin levels to a greater extent than visceral fat (Takahashi et al. 1996).

In addition to UCP1 and UCP2 gene expression, the present report examined the effect of leptin administration on several other transcripts involved in energy balance, including LPL, HSL, $\beta_{3} \mathrm{AR}$, and leptin. Leptin increases sympathetic nerve activity and norepinephrine turnover in BAT (Collins et al. 1996, Haynes et al. 1997). Along with UCP1, LPL is another gene that is believed to be regulated by $\beta$-adrenergic stimulation of BAT (Trayhurn et al. 1995a). This enzyme is involved in the assimilation of triglycerides into both BAT and WAT by hydrolyzing lipoprotein triglycerides before their importation into adipocytes (Auwerx et al. 1992). LPL gene expression has a unique pattern of regulation: mRNA levels are upregulated by $\beta$-adrenergic stimulation in BAT, but downregulated in WAT (Auwerx et al. 1992, Trayhurn et al. 1995a). The results of the present study indicate that there are parallel increases in UCP1 and LPL mRNA in BAT after administration of leptin compared with levels in foodrestricted rats. Food restriction, however, diminished UCP1 mRNA levels, whereas there was no change in LPL mRNA levels in BAT. These data suggest that UCP1 
and LPL are regulated differently in BAT, and support our recent study indicating that denervation of BAT prevents the leptin-induced increase in UCP1 mRNA but not the leptin-induced increase in LPL mRNA (Scarpace \& Matheny 1998). In contrast to the effects on BAT, we found that administration of leptin reduced LPL expression in WAT, but this reduction was most probably secondary to the leptin-induced decrease in food consumption: that is, leptin had no effect on LPL expression in food-restricted rats. This decrease in LPL mRNA levels in WAT of food-restricted animals may be the physiological response to the diminished demand for lipid assimilation into WAT during the period of food restriction.

Surprisingly, $\beta_{3} \mathrm{AR}$ mRNA levels were unchanged by leptin in BAT or WAT. We and others have demonstrated that administration of a $\beta_{3}$-adrenergic agonist downregulates $\beta_{3}$ AR mRNA in BAT (Granneman \& Lahners 1992, Kumar \& Scarpace 1998). It is plausible that the putative leptin-induced increase in sympathetic activation of BAT is not sufficient to down-regulate $\beta_{3} \mathrm{AR}$ mRNA levels, or that down-regulation occurred earlier in the course of the leptin treatment and had adapted by 1 week of treatment.

Leptin gene expression is also inhibited by treatment with a $\beta$-adrenergic agonist (Slieker et al. 1996, Li et al. 1997). In addition, leptin gene expression is stimulated by insulin and glucocorticoids (De Vos et al. 1995, Slieker et al. 1996, Wabitsch et al. 1996, Zheng et al. 1996). These hormonal modulators exert their effects directly on WAT and have been demonstrated both in vivo after hormone administration (De Vos et al. 1995, Zheng et al. 1996, Li et al. 1997) and in vitro in isolated white adipocytes (Slieker et al. 1996, Wabitsch et al. 1996). Glucocorticoids and insulin may mediate the increase in leptin expression after ingestion of a meal, whereas circulating catecholamines or sympathetic activation may mediate the fasting-induced suppression of leptin gene expression.

In the present study, we demonstrated a suppression of leptin gene expression after administration of leptin. The decrease in food intake with leptin treatment may be contributing to this diminished leptin gene expression. The level of food ingestion may alter serum insulin or corticosterone concentrations, alleviating these stimulatory signals, or it may increase adrenergic stimulation of WAT, activating $\beta_{3}$-adrenergic receptors and the subsequent inhibition of leptin gene expression, or both. We demonstrated that food restriction alone suppressed leptin mRNA levels compared with rats fed ad libitum. Moreover, we demonstrated that there was a component of the suppression of leptin gene expression that was independent of food intake. In food-restricted rats, leptin treatment diminished leptin gene expression in both PWAT and EWAT. This decrease in leptin gene expression was not the result of a decrease in either insulin or corticosterone concentrations, as those were unchanged. Thus, in the leptin-treated rats, there was both a food-dependent and a food-independent suppression of leptin mRNA levels.

The decrease in leptin mRNA levels was evident whether expressed per unit RNA, per unit DNA, or per total WAT depot. In addition to the diminished food intake after administration of leptin, there was a decrease in the weight of the PWAT and EWAT depots. However, total RNA and DNA per WAT depot were unchanged, suggesting the loss of weight was due to a decrease in lipid content and, thus, an apparent decrease in cell size.

There are several possible mechanisms that could be contributing to the decrease in leptin mRNA after administration of leptin. First, the decrease in cell size could result in reduced leptin gene expression. However, there was a strong correlation between the increase in UCP2 mRNA and the decrease in leptin mRNA, and UCP2 mRNA was not altered by cell size. For example, food restriction decreased the apparent cell size without a concomitant change in UCP2 mRNA levels in EWAT. Another possibility is that the leptin-induced decrease in leptin expression may be a result of direct feedback through a leptin receptor on adipocytes - leptin downregulated its own expression. The leptin receptor has been identified on adipocytes (Lee et al. 1996). Furthermore, the strong correlation between the decrease in leptin mRNA and the increase in UCP2 mRNA suggests that both of these processes are mediated by the same pathway, possibly a leptin receptor. Alternatively, the suppression of leptin gene expression by leptin administration may be indirect, and mediated by some other regulator of leptin gene expression.

In summary, the findings of this study indicate that leptin increases the gene expression of UCP2 in EWAT and UCP3, UCP1 and LPL in BAT, whereas reduced food consumption, but not leptin, decreases LPL expression in WAT. Food restriction diminished UCP1 but not LPL mRNA levels in BAT, suggesting that these transcripts are regulated differently in BAT. In addition, there is a leptin-associated decrease in leptin mRNA levels that is independent of food intake and serum insulin and corticosterone concentrations. Furthermore, these data suggest that the mechanism by which leptin increases energy expenditure is through increased uncoupled respiration both in WAT, involving increased expression of $\mathrm{UCP} 2$, and in BAT, involving increased expression of UCP1 and UCP3.

\section{Acknowledgements}

Supported by the Medical Research Service of the Department of Veterans Affairs and National Institute on Aging Grant AG-11465. 


\section{References}

Auwerx J, Leroy P \& Schoonjans K 1992 Lipoprotein lipase: recent contributions from molecular biology. Critical Reviews in Clinical Laboratory Sciences 29 243-268.

Boss O, Samec S, Dulloo A, Seydoux J, Muzzin P \& Giacobino JP $1997 a$ Tissue-dependent upregulation of rat uncoupling protein-2 expression in response to fasting or cold. FEBS Letters 412 111-114.

Boss O, Samec S, Paoloni-Giacobino A, Rossier C, Dulloo A, Seydoux J, Muzzin P \& Giacobino J-P $1997 b$ Uncoupling protein-3: a new member of the mitochondrial carrier family with tissue-specific expression. FEBS Letters 408 39-42.

Boss O, Samec S, Kuhnet F, Bijlenga P, Assimacopoulos-Jeannet F, Seydoux J, Giacobino J-P \& Muzzin P 1998 Uncoupling protein-3 expression in rodent skeletal muscle is modulated by food intake but not by changes in environmental temperature. Journal of Biological Chemistry 273 5-8.

Campfield LA, Smith FJ, Guisez Y, Devos R \& Burn P 1995 Recombinant mouse ob protein: evidence for a peripheral signal linking adiposity and central neural networks. Science 269 546-549.

Chomczynski P \& Sacchi N 1987 Single-step method of RNA isolation by acid guanidinium thiocyanate-phenol-chloroform extraction. Analytical Biochemistry 162 156-159.

Collins S, Kuhn CM, Petro AE, Swick AG, Chrunyk BA \& Surwit RS 1996 Role of leptin in fat regulation. Nature 380677

De Vos P, Saladin R, Auwerx J \& Staels B 1995 Induction of ob gene expression by corticosteroids is accompanied by body weight loss and reduced food intake. Journal of Biological Chemistry $\mathbf{2 7 0}$ 15958-15961.

Enerback S, Jacobsson A, Simpson EM, Guerra C, Yamashita H, Harper M-E \& Kozak LP 1997 Mice lacking mitochondrial uncoupling protein are cold-sensitive but not obese. Nature $\mathbf{3 8 7}$ 90-94.

Fleury C, Neverova M, Collins S, Raimbault S, Champigny O, Levi-Meyrueis C, Bouillaud F, Seldin MF, Surwit RS, Ricquier D \& Warden CH 1997 Uncoupling protein-2: a novel gene linked to obesity and hyperinsulinemia. Nature Genetics 15 269-272.

Gong D-W, He Y, Karas M \& Reitman M 1997 Uncoupling protein-3 is a mediator of thermogenesis regulated by thyroid hormone, $\beta_{3}$-adrenergic agonists, and leptin. Journal of Biological Chemistry 272 24129-24132.

Granneman JG 1991 Effects of agonist exposure on the coupling of

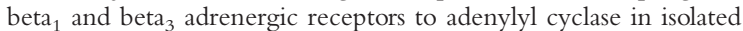
adipocytes. Journal of Pharmacology and Experimental Therapeutics 261 638-642.

Granneman JG \& Lahners KN 1992 Differential adrenergic regulation of $\beta_{1}$ - and $\beta_{3}$-adrenoreceptor messenger ribonucleic acids in adipose tissue. Endocrinology 130 109-114.

Halaas JL, Gajiwala KS, Maffei M, Cohen SL, Chait BT, Rabinowitz D, Lallone RL, Burley SK \& Friedman JM 1995 Weight-reducing effects of the plasma protein encoded by the obese gene. Science 269 543-546.

Haynes WWG, Morgan DA, Walsh SA, Mark AL \& Sivitz WI 1997 Receptor-mediated regional sympathetic nerve activation by leptin. Journal of Clinical Investigation 100 270-278.

Hotta K, Gustafson A, Ortmeyer HK, Bodkin NL, Nicolson MA \& Hansen BC 1996 Regulation of obese (ob) mRNA and plasma leptin levels in rhesus monkeys. Journal of Biological Chemistry 271 25327-25331.

Klingenberg M 1990 Mechanism and evolution of the uncoupling protein of brown adipose tissue. Trends in Biochemical Sciences $\mathbf{1 5}$ 108-112.

Kozak LP, Britton JH, Kozak UC \& Wells JM 1988 The mitochondrial uncoupling protein gene. Journal of Biological Chemistry $26312272-12277$.

Kumar MV \& Scarpace PJ 1998 Differential effects of retinoic acid on uncoupling protein and leptin gene expression. Journal of Endocrinology 157 237-243.
Labarca C \& Paigen K 1980 A simple, rapid, and sensitive DNA assay procedure. Analytical Biochemistry 102 344-352.

Larkin S, Mull E, Miao W, Pittner R, Albrandt K, Moore C, Young A, Denaro M \& Beaumont K 1997 Regulation of the third member of the uncoupling protein family, UCP3, by cold and thyroid hormone. Biochemical and Biophysical Research Communications $240222-227$

Lee GH, Proenca R, Montez JM, Carroll KM, Darvishzadeh JG, Lee JI \& Friedman JM 1996 Abnormal splicing of the leptin receptor in diabetic mice. Nature 379 632-635.

Li H, Matheny M \& Scarpace PJ $1997 \beta_{3}$-Adrenergic mediated suppression of leptin gene expression in rats. American Journal of Physiology 272 E1031-E1036.

Millet L, Vidal H, Andreelli F, Larrouy D, Riou J-P, Ricquier D, Laville M \& Langin D 1997 Increased uncoupling protein-2 and -3 mRNA expression during fasting in obese and lean humans. Journal of Clinical Investigation 100 2665-2670.

Murakami T \& Shima K 1995 Cloning of rat obese cDNA and its expression in obese rats. Biochemical and Biophysical Research Communications 209 944-952.

Pelleymounter M, Cullen MJ, Baker MB, Hecht R, Winters D, Boone T \& Collins F 1995 Effects of the obese gene product on body weight regulation in ob/ob mice. Science 269540 543.

Saladin R, De Vos P, Guerre-Millo M, Leturque A, Girard J, Staels B \& Auwerz J 1995 Transient increase in obese gene expression after food intake or insulin administration. Nature 377 527529.

Scarpace PJ \& Matheny M 1998 The leptin induction of UCP1 is dependent on sympathetic innervation. American Journal of Physiology 275 E259-E264.

Scarpace PJ, Matheny M \& Borst SE 1992 Thermogenesis and mitochondrial GDP binding with age in response to the novel agonist CGP-12177A. American Journal of Physiology 262 E185-E190.

Scarpace PJ, Matheny M, Borst S \& Tümer N 1994 Thermoregulation with age: role of thermogenesis and uncoupling protein expression in brown adipose tissue. Proceedings of the Society for Experimental Biology and Medicine 205 154-161.

Scarpace PJ, Matheny M, Pollock BH \& Tümer N 1997 Leptin increases uncoupling protein expression and energy expenditure. American Journal of Physiology 273 E226-E230.

Slieker LJ, Sloop KW, Surface PL, Kriauciunas A, LaQuier R, Manetta J, Bue Valleskey JB \& Stephens TW 1996 Regulation of expression of ob mRNA and protein by glucocorticoids and cAMP. Journal of Biological Chemistry 271 5301-5304.

Takahashi M, Funahashi T, Shimomura I, Miyaoka K \& Matsuzawa Y 1996 Plasma leptin levels and body fat distribution. Hormone and Metabolic Research 28 751-752.

Trayhurn P, Duncan JS \& Rayner DV 1995a Acute cold-induced suppression of ob (obese) gene expression in white adipose tissue of mice: mediation by the sympathetic system. Biochemical Journal 311 729-733.

Trayhurn P, Thomas MEA, Duncan JS \& Rayner DV 1995b Effects of fasting and refeeding on ob gene expression in white adipose tissue of lean and obese $(\mathrm{ob} / \mathrm{ob})$ mice. FEBS Letters $\mathbf{3 6 8}$ 488-490.

Vidal-Puig A, Solanes G, Grujic D, Flier JS \& Lowell BB 1997 UCP3: an uncoupling protein homologue expressed preferentially and abundantly in skeletal muscle and brown adipose tissue. Biochemical and Biophysical Research Communications 235 79-82.

Wabitsch M, Jensen PB, Blum WR, Christoffersen CT, Englaro P, Heinze E, Rascher W, Taller W, Tornqvist H \& Hauner H 1996 Insulin and cortisol promote leptin production in cultured human fat cells. Diabetes 45 1435-1438. 
Zhang Y, Proenca R, Maffei ZM, Barone M, Leopold L \& Friedman J 1994 Positional cloning of the mouse obese gene and its human homologue. Nature 372 425-432.

Zheng D, Jones JP, Usala SJ \& Dohm GL 1996 Differential expression of ob mRNA in rat adipose tissues in response to insulin. Biochemical and Biophysical Research Communications 218 434-437.

Zhou YT, Shimabukuro M, Koyama K, Lee Y, Wang M-Y, Trieu F, Newgard CB \& Unger RH 1997 Induction by leptin of uncoupling protein-2 and enzymes of fatty acid oxidation. Proceedings of the National Academy of Sciences of the USA 94 6386-6390.

Received 2 February 1998

Revised manuscript received 1 June 1998 Accepted 8 July 1998 